\title{
Processing Trade, Exchange Rates and China's Bilateral Trade Balances
}

By

\section{Yuqing Xing}

Jan 2011

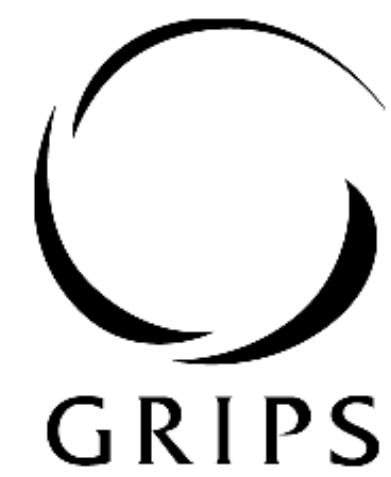

National Graduate InStitute For POLICY STUdies

National Graduate Institute for Policy Studies 7-22-1 Roppongi, Minato-ku, Tokyo, Japan 106-8677 


\title{
Processing Trade, Exchange Rates and China's bilateral Trade Balances
}

\author{
Yuqing Xing ${ }^{\star}$ \\ National Graduate Institute for Policy Studies, \\ Tokyo
}

\begin{abstract}
This paper analyzed the role of processing trade in China's bilateral trade balances and the impact of the yuan's appreciation on processing trade. The analysis is based on a panel data covering China's 51 major trading partners from 1993-2008. The empirical analysis shows that: (1) processing trade accounted for $100 \%$ of China's overall trade surplus and could explain most of China's bilateral trade balances; (2) China's processing trade shows a significant regional bias. While China has maintained a surplus with all G-7 countries in processing trade, it has run a significant deficit with most of East Asian economies; (3) East Asian economies are major sources and account for $77 \%$ of China's processing imports. The econometric analysis reveals that processing imports from East Asian is eleven times of that from other regions; (4) the response of processing imports to the yuan's appreciation differs with that of normal trade. Specifically, a $10 \%$ real appreciation of the yuan will reduce rather than increase China's processing imports by $3.9 \%$. Given that processing exports will decrease $9.6 \%$ for the same appreciation and China's trade surplus is mainly generated from processing trade, a moderate appreciation of the yuan would have a very limited impact on China's trade balance.
\end{abstract}

Key Words: Processing Trade, Exchange Rates, China JEL Classification: F1

\footnotetext{
* National Graduate Institute for Policy Studies, 7-22-1 Roppongi, Minato-ku, Tokyo, 106-8677, Japan. Email: yuqing_xing@grips.ac.jp. The author is grateful to the comments of Mario Lamberte, Willem Thorbecke, Yang Yao and other participants at the ADBI seminar and the Beijing Forum 2010. The author thanks ADBI for its financial support. The research also benefits from a grant of Japan Society for Promotion of Science (No. 21530214).
} 


\section{Introduction}

Global imbalances have been argued as one of major reasons responsible for the global financial crisis and the subsequent economic recession in the US and European countries. In searching for the roots of global imbalances, most of debates and studies focus on macro factors such as insufficient domestic consumption in China, low saving rates in the US and the inflexibility of China's exchange rate regime. With a record high of US $\$ 349$ billion surplus in goods and services in 2008 , China has been urged to boost its domestic consumption and re-value the yuan to mitigate the trade surplus for rebalancing the global economy. On the other hand, little attention has been given to micro factors, such as the structures of trade, the proliferations of cross-country production fragmentation and production networks developed in East Asia. With unprecedented liberalization in trade and capital mobility, these micro factors have re-shaped trade patterns, transformed implications of trade statistics, and affected bilateral trade balances. Therefore, it is imperative to analyze China's trade balances in a broad context and assess the importance of the structure variables in determining trade patterns and bilateral trade balances.

China's trade differs with conventional international trade modeled in standard textbooks. First of all, foreign invested firms produced more than half of China's exports. In some commodities such as electronics and information communication technology (ICT), foreign invested firms have dominated China's exports and accounted for more than $80 \%$ of the exports (Xing, 2010). Besides low labor cost, advanced technology and production know-how associated with foreign direct investment (FDI), brand names and distribution networks of multinational enterprises (MNE) all contributed to the rapid expansion of China's exports. In other words, it is the combination of foreign capital and technology with China's rich labor endowments that has been powering the sustained high growth of China's exports. In conventional trade theory, however, all technologies determining comparative advantages or needed for utilizing abundant resources are assumed indigenous and existing.

Secondly, processing trade accounted for more than $41 \%$ of China's total trade. In terms of the scale of processing trade and the range of commodities involved, the significance of processing trade in China's external trade is unmatched. The extraordinary high share of processing trade is a result of China's integration with the world economy, the 
extension of cross-country production fragmentation into China, and the development of production networks in East Asia. Processing trade reversed conventional trade patterns such that developing countries, say China, export high-tech products while industrialized countries like the US imports high-tech goods. For instance, China has a comparative advantage in labor intensive products. However, according to an OECD report, China has surpassed the US and Japan and emerged as the leading exporting country of ICT (2005, OECD). Moreover, with processing trade, bilateral trade balances between a country used as an export-platform and destination markets of final products are inflated, as the former needs to import a large amount of intermediate inputs from third countries for processed exports.

A typical example of processing trade is the trade of iPhones between China and the US. iPhones, the most trendy and advanced mobile, are exclusively assembled in China. All parts and components used for iPhones are produced in Germany, Japan, Korea, Taiwan and the US, then shipped to China for assembling the ready to use final products, which are exported to the US and other markets. In terms of conventional trade statistics, the production fragmentation and networks involved in manufacturing iPhones have created a non-traditional trade pattern: iPhones invented by the US company Apple are exported to the US from China, which does not have a comparative advantage in producing smart phones at all. It is estimated that iPhone trade contributed US\$1.9 billion to the trade deficit of the US with China in 2009. Measured in value-added created by Chinese workers assembling iPhones, however, the US would have US\$48 million surplus from the iPhone trade with China. This means that the deficit was simply a transfer from the third countries, which supply parts and components to Foxconn, an exclusive iPhone assembler located in Shenzhen, China (Xing and Deter, 2010).

There is a plethora of studies on China's processing trade (e.g, Aziz and Li, 2007; Koopma, Wang, and Wei, 2008; Thorbecke, 2010; Thorbecke and Smith, 2010; Ahmed, 2009). All of these studies primarily concentrated on the relationship between the yuan's exchange rates and the volume of processing trade and based on time series data. One of the pitfalls in the existing literature is that the role of production networks in East Asian and geographic factors were ignored. It is imperative to include factors representing production networks and regional factors in examining the determination of China's processing trade because assembling parts into finished products is one of the 
production processes. MNE affiliated Chinese firms are major players of processing trade, and most of processing imports originate from East Asian economies. This study attempts to investigate China's processing trade in a broad framework with emphasis on both regional factors and the yuan's exchange rates. It is based on a panel data covering China's bilateral processing trade with 51 trading partners from 1993 to 2008 . These trading partners accounted for $99 \%$ of China's processing trade. The panel data allows us to address the regional factor in processing trade.

The simply descriptive analysis show that, processing trade accounted for $100 \%$ of China's trade surplus and explained most of China's bilateral trade balances with its major trading partners. By decomposing processing imports according to their origins, we found that China is one of the major sources of the processing imports and counted for $16.8 \%$. This is the first empirical study that uncovered the role of China in supplying processing imports. The result has very important implications for assessing the value added of China's processing exports and the effectiveness of the value added tax rebates implemented by the Chinese government for promoting exports. For identifying major factors that determine processing exports and imports, an augmented gravity model with country-dummies was estimated. The estimates of the gravity model suggest that China's processing trade has a significant regional bias. The processing exports to the East Asian Economies are three times higher than that to other regions while the processing imports from the East Asian economies are more than eleven times higher. With regards to exchange rates, the estimates suggest that the real appreciation of the yuan would reduce not only China's processing exports but also processing imports. Specifically, a $10 \%$ real appreciation will lead to $9.6 \%$ decrease in processing exports and $3.9 \%$ drop in processing imports. This result is consistent with the fact that processing imports serve as intermediate inputs of processed exports. If processing exports fall, processing imports should fall too.

\section{Literature Review}

Without advanced technology, brand names and global marketing networks, it is difficult for products of developing countries to penetrate the world market, in particular the market of industrialized countries. Processing trade provides a shortcut for developing countries to join the international division of labors and utilize their abundant labor forces. Processing trade involves importing parts and components from abroad as intermediate 
inputs, processing and assembling these intermediate inputs into finished products, and eventually re-exporting processed products to the global market via international distribution and retail networks of MNEs. Trade liberalization and declined transportation costs have greatly facilitated the development of cross-country production fragmentation and production process specializations. China's economic reform in the last three decades has provided opportunities for MNEs to integrate China into their production networks and utilize China as a low cost assembling base.

Processed exports are made of both imported and domestically produced parts and components. The share of domestically made contents determines the domestic contribution in the value added of exports and the extent of various policy impacts on the trade volume. To calculate the share of domestic contents in China's processing exports, Koopman, Wang and Wei(2008) applied the input-output method to estimate domestic contents in China's exports by sectors. They found that the share of domestic valued added is high in normal exports about 88 to $95 \%$, but low in processing exports between 18 to $26 \%$. Local firms engaging in processing trade are generally exposed to production know-how and product designs of foreign companies. Processing trade also functions as an effective channel for knowledge spillovers, which contributed substantially to the productivity growth of domestic firms. Using firm level data, Yu (2010) showed that processing trade has been a significant channel for technology spillovers to local Chinese companies.

Most studies on China's processing trade focus on the nexus of real exchange rates and trade balances. Garcia-Herrero and Koivu (2009) used co-integration techniques to estimate the long-run elasticities of China's processing exports and imports to real exchange rates. Based on monthly time series data from 1994 to 2005, they showed that China's processing exports would be expected to decrease $1.3 \%$ for every $1 \%$ appreciation of the yuan, and processing imports would decrease too when the yuan appreciates.

Chung, Chinn, and Fuijii (2009) investigated this similar issue over a relatively longer period, between 1980 to 2006. They converted monthly data into quarterly by simple averaging, and estimated both processing export and import equations with the dynamic OLS regression. Their empirical findings contradict the expectation of the conventional 
theory, indicating that China's processing exports would increase 1.86 to $2.68 \%$ for every $1 \%$ real appreciation of the yuan rather than decrease.

Aziz and Li (2007) analyzed the dynamic changes of the export elasticity to real exchange rates from 1995 to 2006 . They found that the price elasticity of China's exports increased over time. After decomposing exports into non-processing and processing exports, they showed that the price elasticity of processing export increase significantly while that of the non-processing exports remained unchanged. Rising domestic content of processing trade was argued as a critical factor affecting the evolution of the export elasticity.

Considering that domestic content represents only a small portion of total value of China's processing trade and a unilateral appreciation by China may create limited impact on China's processing exports, Thorbecke and Smith (2010) analyzed not only the impact of a unilateral appreciation of the yuan on China's processing exports, but also a joint appreciation of the currencies of all East Asian economies. They constructed an integrated exchange rate-a weighted exchange rate between the yuan and the currencies of other East Asian economies according to the importance of their trade with China. The integrated exchange rate is used to measure the join appreciation of the other East Asian economies. They argued that a joint appreciation is more effective than an unilateral appreciation, because a unilateral appreciation of the yuan by $10 \%$ would reduce China's processing exports by $4 \%$ while a joint appreciation of $10 \%$ on all currencies of the East Asian economies would reduce China's exports by $10 \%$.

Thorbecke (2010) used extended data from 1992 to 2008 to re-estimate the effect of the integrated exchange rate on China's processing export and found that the elasticity of processing exports to the integrated exchange rate is around 1 , consistent with the previous result. In addition, he estimated the elasticity of processing imports and showed that a $10 \%$ joint appreciation of the East Asian currencies would increase Chinese processing imports between 3.9 to $4.1 \%$. Ahmad (2009) also showed that the joint appreciation of the yuan and the currencies of China's major processing trade partners would be more effective in curbing the growth of China's processing trade. However, the study did not analyze the sensitivity of processing imports to variations of exchange rates. 


\section{The Stylized Facts of China's Processing Trade}

\section{Sources of Processing Imports}

China's processing trade shows a distinctive geographic feature. The sources of China's processing imports primarily cluster around East Asian economies. Among the top ten sources, which accounted for $88 \%$ of total processing imports in 2008 , eight were from East Asia: Taiwan, China, Japan, Korea, Malaysia, Thailand, The Philippines and Singapore (Figure 1). These eight East Asia economies together accounted for US $\$ 294$ billion, or about $77 \%$ of the total processing imports. Taiwan is the largest single source for China's processing imports; US\$64 billion processing imports came from Taiwan. Japan and Korea were third and fourth largest with US\$ 61.3 billion and US\$ 59.1 billion respectively. Among the top ten, the US and Germany were the only two non-East Asian economies among the top ten. Even though Germany is the fourth largest economy in the world, it accounted for only US\$7.2 billion processing imports, much smaller than that from Malaysia, Thailand, The Philippines, or Singapore.

There are three reasons why the East Asian economies have become the main sources of China's processing imports. First of all, Japan, Taiwan, Korea and Singapore are the major sources of FDI in China. From 1985 to 2008, cumulative FDI from these four economies amounted US\$192 billion. Excluding Hong Kong, Japan is the largest FDI source for China (Xing, 2010). Secondly, MNEs from these economies have built up their production networks in East Asia. Abundant labor endowment makes China an ideal place for processing and assembling parts and components into finished products for the world market. With direct investment, MNEs from East Asian economies have extended their production networks and integrated China into their production chains (Kimura, 2010). Finally, Taiwanese manufacturers have been the leading original equipment makers (OEM) for information communication technology, such as personal computers, laptop computers, servers, etc. They have relocated their production facilities, into mainland China, boosting China's processing trade in ICT substantially (Xing, 2010).

It is noteworthy that in 2008 , US $\$ 61$ billion process imports were originally produced in China, making China the second largest source of its own processing imports. These processing imports were first manufactured by domestic firms, then exported to Hong Kong, and eventually re-imported back as intermediate inputs by firms producing exports. 
For promoting exports, the Chinese government has been offering value added tax rebates to exporting firms. With the round-tripping of domestically made products between China and Hong Kong, the exporting firms are able to receive $17.5 \%$ value added tax rebates while importing firms benefit from the reduced prices. In 1993, the processing imports originating from China amounted to US $\$ 1.1$ billion, about $2.9 \%$ of the total processing imports. By 2008 , the share surged to $16.2 \%$, suggesting that the tax incentive has been very effective in promoting both exports and imports. In the literature on processing trade, the role of China as an important source of processing import has been ignored. Given that a substantial amount of imported parts and components were actually made in China, it is highly possible that the domestic contents of processing exports were underestimated by the existing literature. In addition, the large volume of the round-tripping of made-in-China products implies that the preferential tax policy is one of critical factors facilitating the high growth of processing trade. Abolishing the tax incentive may be more effective for curbing trade surpluses and rebalancing the growth path of the Chinese economy.

\section{Figure 1}

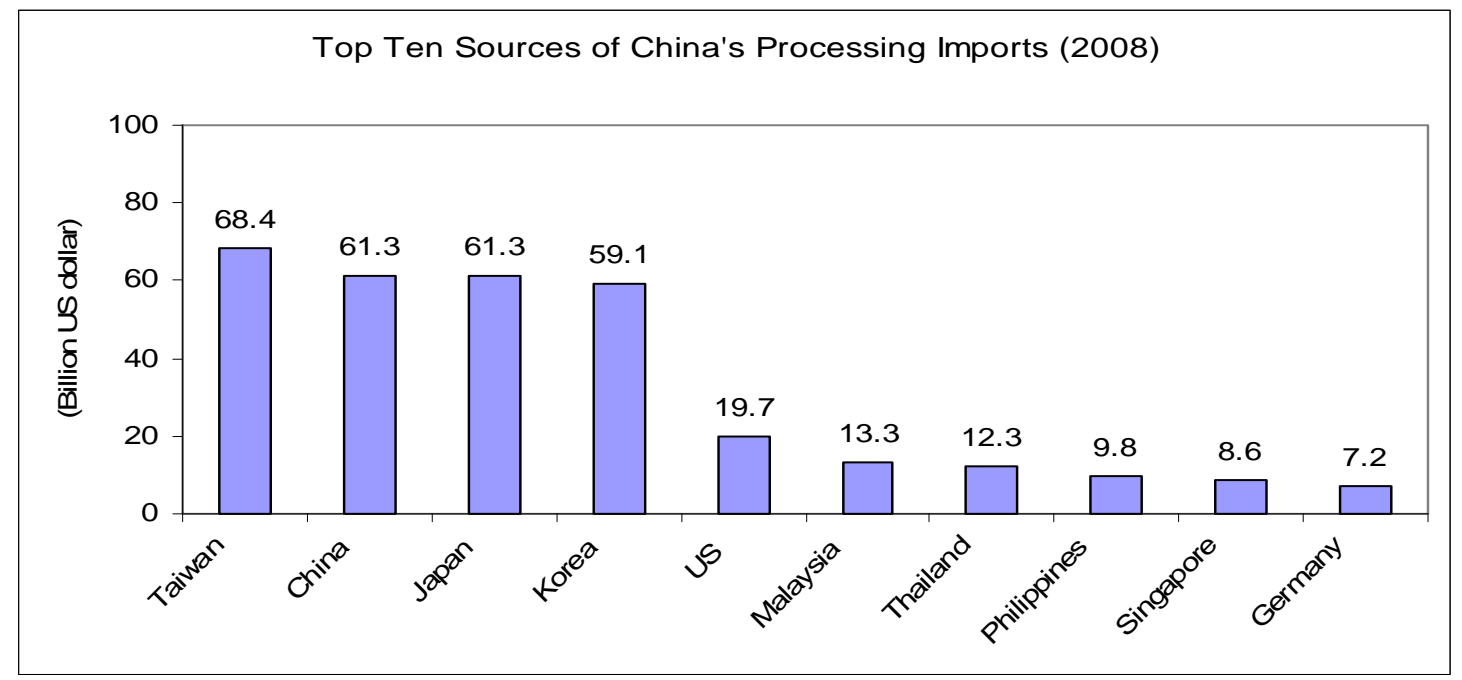

Source: The author's calculations based on the data provided by China Customs.

\section{Destination Markets of Processing Exports}

In the same fashion, the top ten destination markets of China's processing exports are listed in figure 2. It is well acknowledged that Hong Kong has functioned as a distribution market for China's products to the rest of the world. In analyzing the top ten markets, Hong Kong was excluded. Instead, the processing exports to Hong Kong were allocated 
to the rest of China's trading partners in proportion to their shares of the total processing exports. The top ten markets together accounted for US $\$ 490$ billion, about $71 \%$ of the total processing exports in 2008. Compared with the sources of processing imports, the destination markets of processing exports are relatively more diversified.

Figure 2

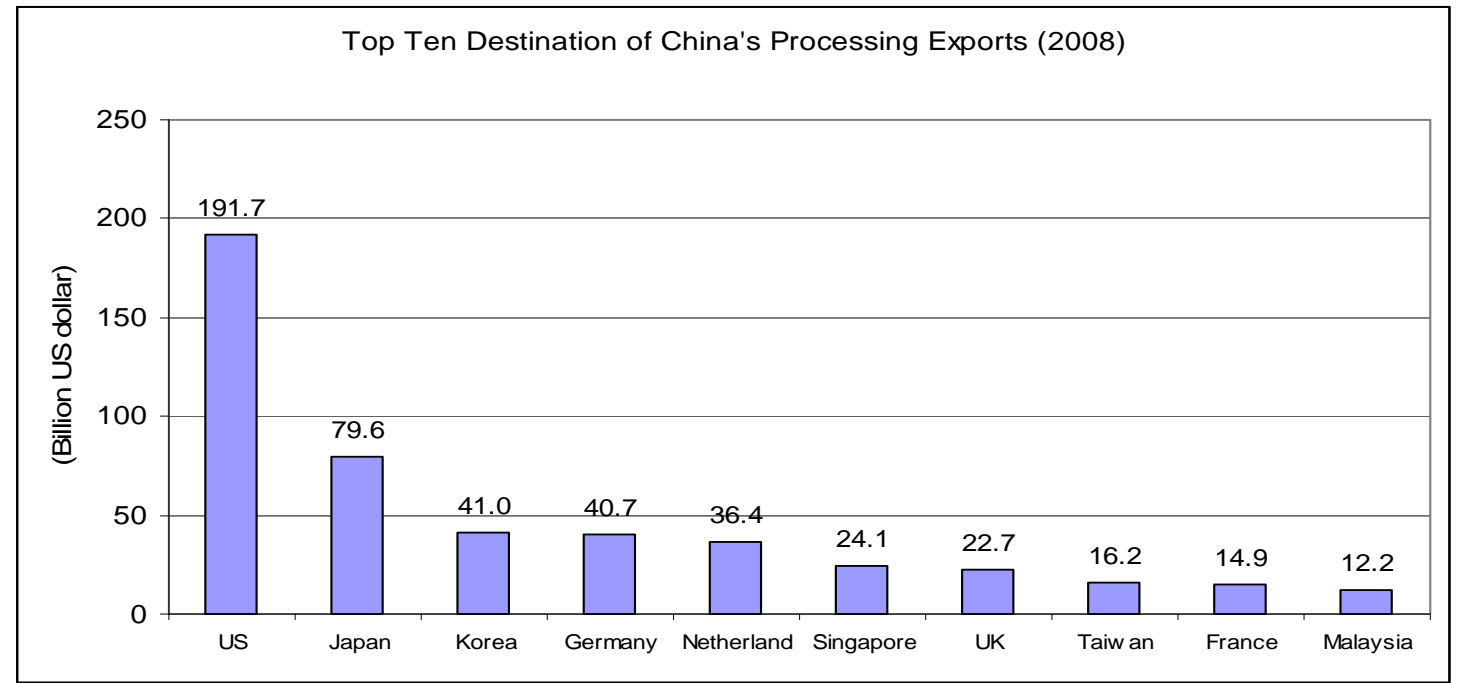

Source: the author's calculations based on the data provided by China's Customs.

The US was the largest single market for China's processing exports. In 2008, US\$192 billion, about $28 \%$ of the total processing exports, was purchased by American consumers. As illustrated in figure 1, the US was also one of the top ten sources of China's processing imports. The volume of the processing imports from the US, however, is only one tenth of the processing exports to the US, implying that the US is much more important as a market rather than as a source of processing trade for China. Japan ranked second with US\$80 billion, followed by Korea with US\$41 billion. Of the top ten destination markets, five are located in East Asia: Japan, Korea, Singapore, Taiwan, and Malaysia. Together these five East Asian economies accounted for US $\$ 173$ billion about $26 \%$ of the total processing exports. Compared with a $77 \%$ share in processing imports, the share of East Asia in China's processing exports is much smaller. This simple descriptive fact suggests that, most of processing imports from East Asian economies are used as intermediate inputs for finished products targeted at third markets; and China has primarily functioned as a big assembling factory for MNEs from East Asian Economies. 
The rest of the top ten destination markets are all from the European Union. They are Germany, The Netherlands, the UK and France. Germany was the fourth largest market, followed by The Netherlands. China's processing exports to these four countries together amounted to US\$115 billion. The different geographic concentrations between processing imports and exports indicate that geographic proximity and production networks in East Asia affected the volume and the pattern of processing trade.

\section{Processing Trade and China's Trade Balance}

According to the statistics of China Customs, in 2008 China had a US\$298 billion trade surplus in goods. It was only US\$5.4 billion in 1994. Decomposing trade into normal and processing trade reveals that, the drastic growth of the trade surplus is mainly due to the rapid expansion of processing trade. Even though processing trade accounted for less than half of China's total external trade, the trade surplus in processing trade in 2008 totaled at US\$297 billion, equivalent to the entire trade surplus. In other words, processing trade contributed almost $100 \%$ of China's trade surplus. Figure 3 shows the evolution of balances in overall and processing trade from 1994 to 2008. The figure unambiguously indicates that the increase in the overall trade surplus is completely attributed to the surplus generated from processing trade. Low skilled labors are the major input for processing and assembling parts and components into finished products. The huge surplus from processing trade is consistent with China's tremendous labor endowment. Further, the mismatching between sources and markets of processing trade implies that, China has been utilized by MNEs from other East Asian economies such as Japan, Korea, Taiwan, and Singapore as a processing center for third country markets; thus a large portion of the processing trade surplus was actually the transferred surplus from these economies to China. 
Figure 3

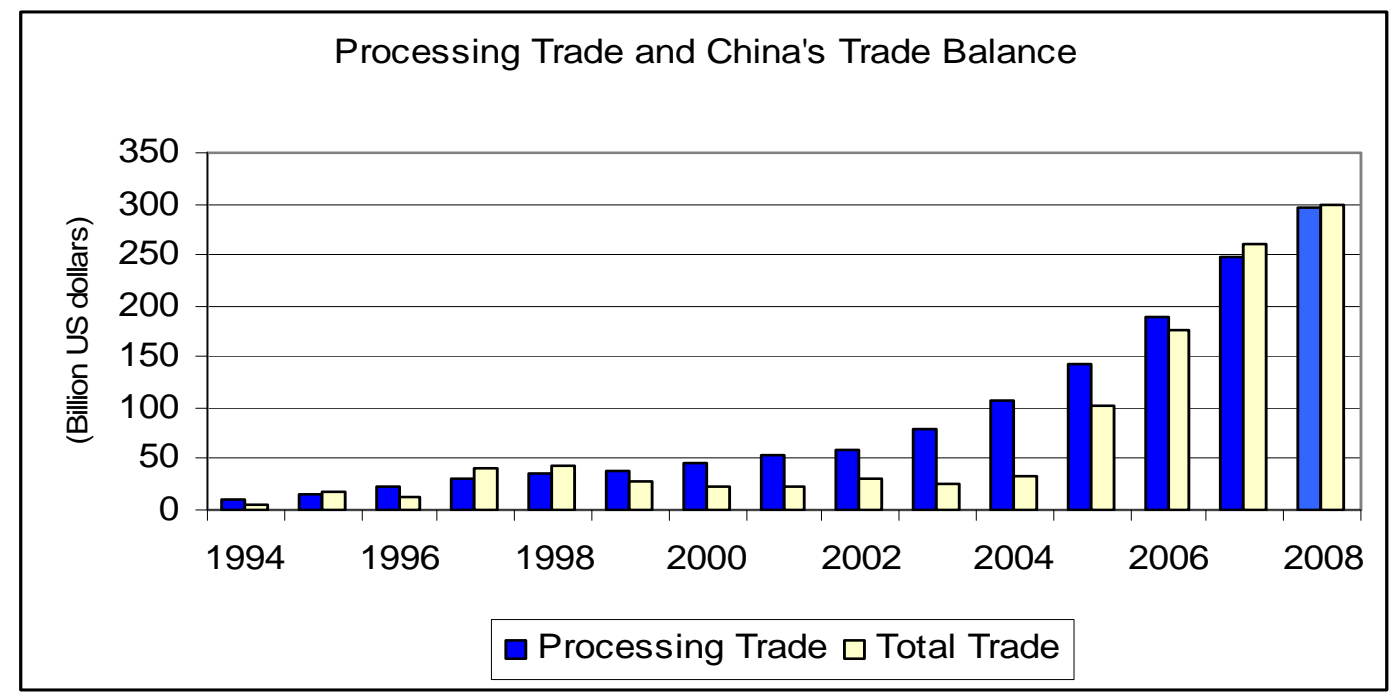

Sources: the author's calculations based on the data of China's Statistics Yearbook

\section{Processing trade and China's bilateral trade balance with Emerging East Asian Economies}

In terms of bilateral trade, processing trade also dominates the direction of China's bilateral trade balances. In spite of maintaining a huge trade surplus in its overall trade, China has been running either trade deficits or relatively small trade surpluses with emerging East Asian economies (Figure 4). China's bilateral balances with these economies in processing trade primarily determined the overall corresponding bilateral trade. Specifically, China had US\$53.6 billion deficit in processing trade with Taiwan and the corresponding overall trade deficit was US\$35.5; with Korea, China had US\$19.3 billion deficit in processing trade and its overall trade deficit was US\$14.5; with The Philippines, China had US $\$ 6.0$ billion deficit in processing trade and US\$0.9 billion in the overall trade. China had a relatively small trade surplus with Thailand and Malaysia. The surplus of these two countries had in processing trade helped reduce their overall trade deficits with China. 
Figure 4

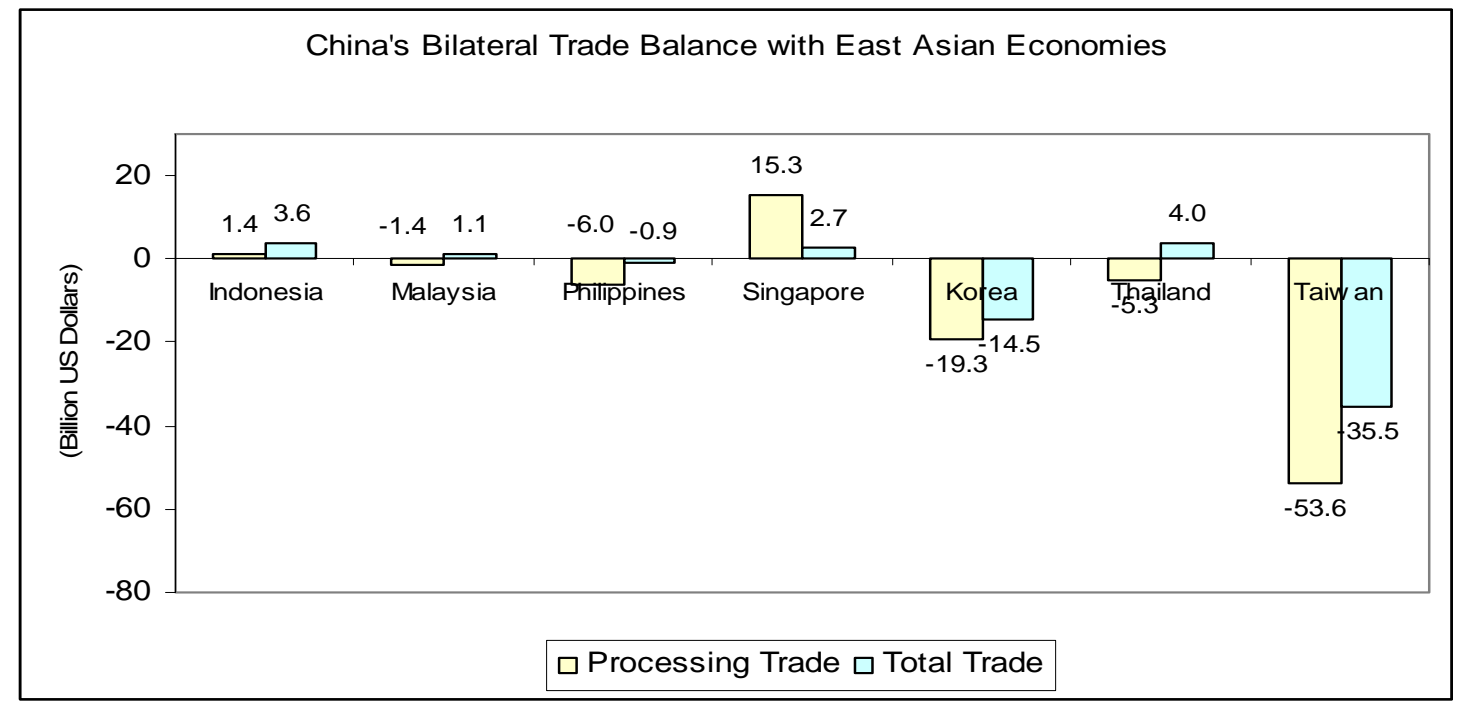

Sources: the author's calculation based on the data provided by China Customs and UNCOMTRDE.

\section{Processing Trade and China's bilateral trade balances with G-7 countries}

Similarly, processing trade also dominates China's bilateral trade balances with the G-7 countries. The trade data reported by the G-7 countries shows that all G-7 countries have had persistent trade deficits with China. Comparing their overall trade deficits along with the balances in processing trade with China indicate that, running a huge deficit in processing trade is one of the major reasons for building up persistent trade deficits (Figure 5). Among the G-7 countries, the US had the largest trade deficit of US $\$ 285$ billion with China in 2008 , of which US $\$ 172$ billion, or about $60 \%$, was attributed to processing trade. Compared with the US, Japan and Germany had much smaller trade deficits simply because they had relatively smaller deficits in processing trade. Japan's deficit in processing trade amounted to US\$18 billion, about one tenth of the US. It explained $100 \%$ of Japan's trade deficit with China. As showed previously, Japan was not only the second largest market for China's processing exports but also the second largest source of China's processing imports. The geographic proximity and export-oriented Japanese FDI in China made Japan the largest source of the processing imports among the G-7 countries, thus limited its overall trade deficit. Germany had US $\$ 33$ billion deficit in processing trade, about $90 \%$ of the total trade deficits. Among the G-7 countries, the U.K. had the second largest trade deficit US $\$ 40.5$ billion with China and half of the deficit originated from processing trade. 
Figure 5

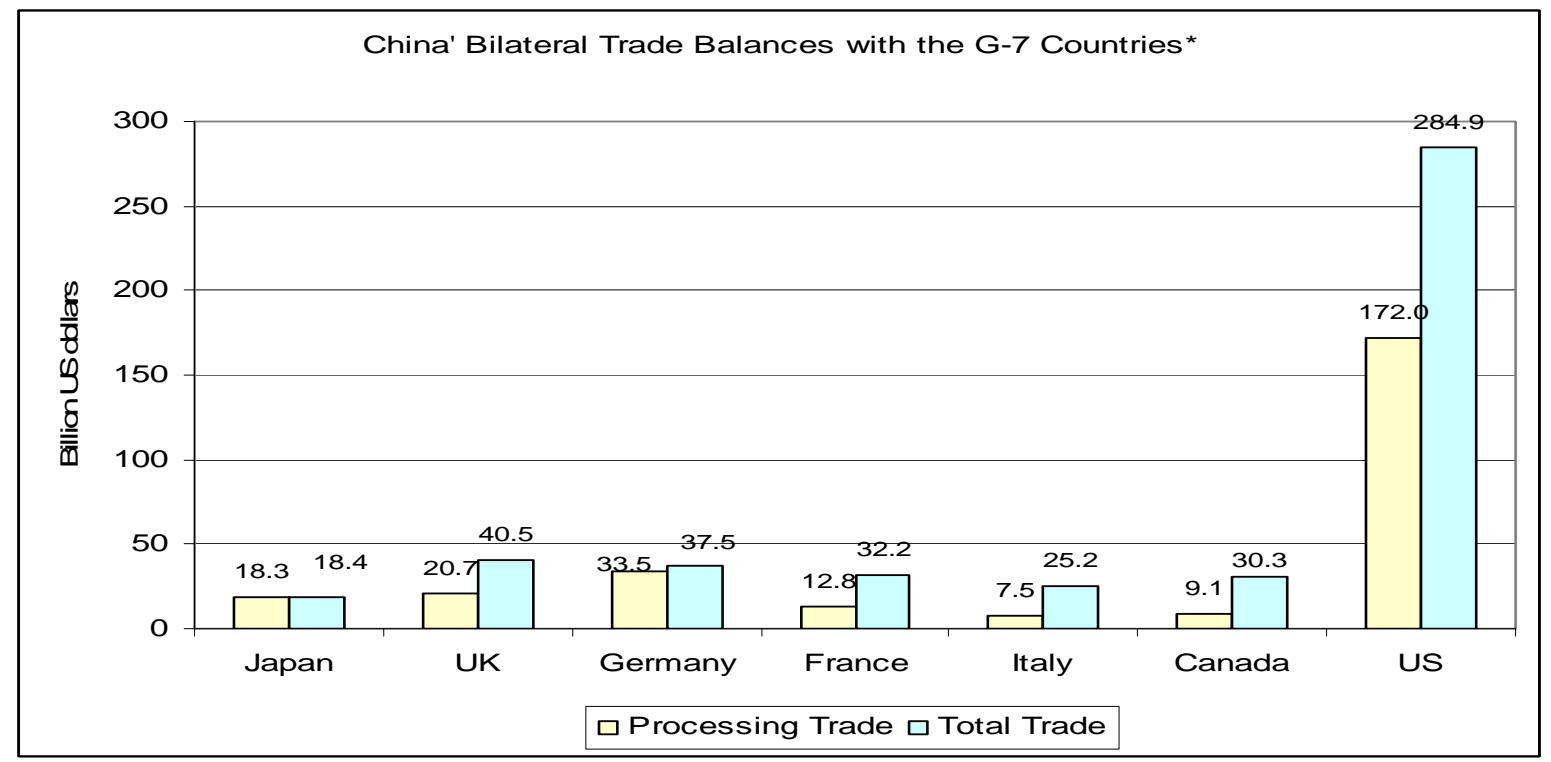

Sources: the author's calculation based on the data of China's Customs and UNCOMTRADE.

\section{Processing Trade and China's bilateral trade balances with $\mathbf{5 1}$ trading partners}

For having a more general picture on the relationship between processing trade and China's bilateral trade balances, the analysis was expanded beyond G-7 and East Asian economies by including 51 of China's major trading partners, which accounted for $99 \%$ of China's processing trade. Using the data of 2008, China's bilateral trade balances with these 51 trading partners and the corresponding bilateral balances in processing trade was calculated. The bilateral trade balances are defined as the ratio of exports to imports (processing exports to processing imports). The scattered chart of bilateral trade balances against balances in processing trade is showed in figure 6 , where the vertical axis measures the logarithm of China's trade balances with each of the selected trading partners and the horizontal axis the logarithm of the corresponding balance in processing trade. The scattered chart implies a strong log-linear relationship between the two variables. In particular, the correlation coefficient was estimated at 0.73 , close to a perfect linear relationship; indicating that the processing trade balances could explain most of China's trade balances with trading partners. In a nutshell, the descriptive analysis on East Asian economies, G-7 countries and the 51 trading partners suggests that, processing trade has determined China's bilateral trade balances. 
Figure 6

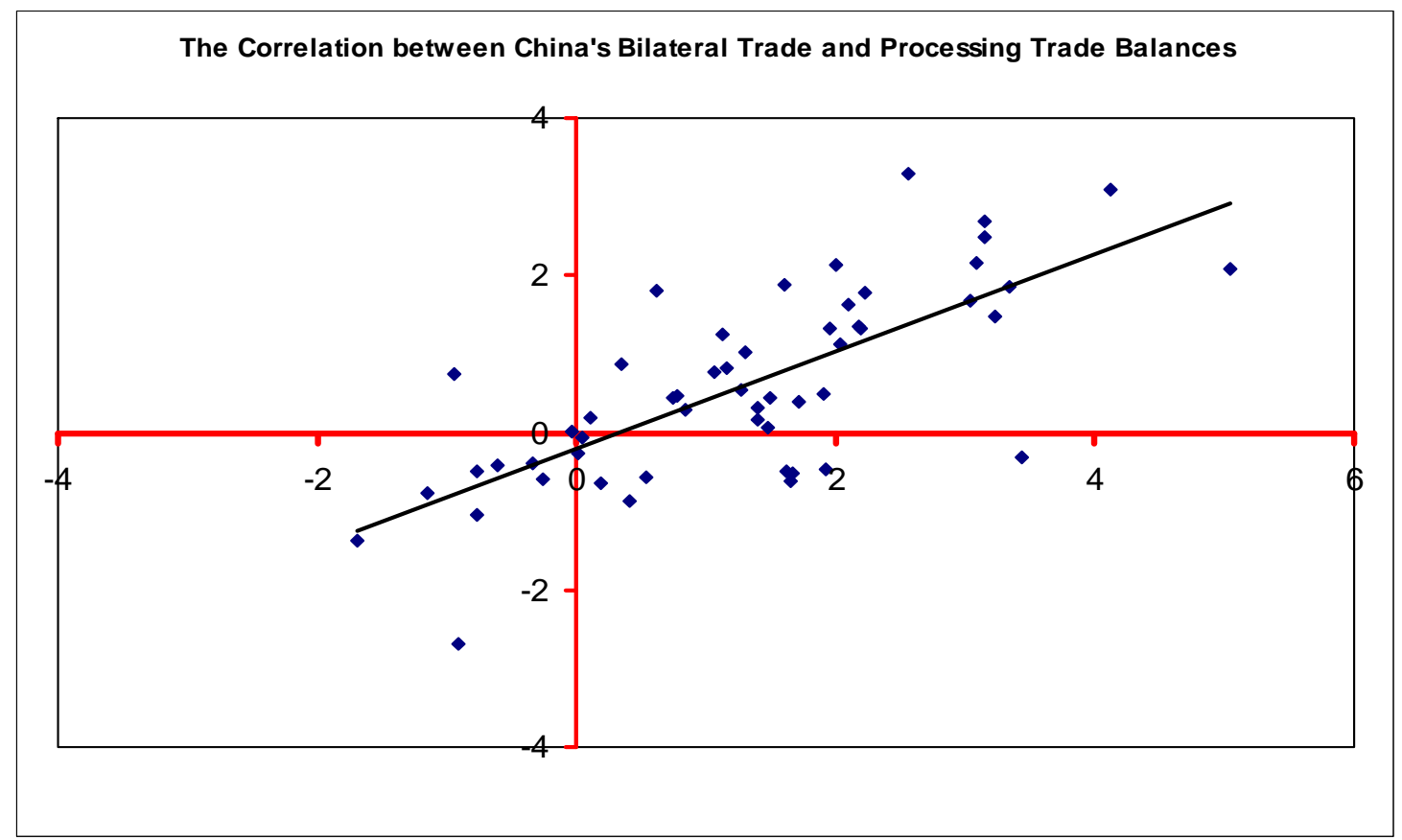

Note: Horizontal Axis: log (processing exports/processing imports); vertical Axis:

$\log$ (exports/imports); the fitted line: a result of a linear regression of the two variables.

\section{Determination of Processing Trade}

Previous sections analyzed the relationship between processing trade and China's overall as well as bilateral trade balances and concluded that processing trade is responsible for $100 \%$ of China's overall trade balance and most of the bilateral trade balances. In this section, I will empirically investigate the factors determining China's processing trade. The empirical analysis is based on the gravity model, which has been used widely as a baseline model for estimating the frontier of bilateral trade, impact of free trade agreements and border effects on trade volumes. Eichengreen and Irwin (1998) called the gravity model the "workhorse for empirical studies" of regional integration. Processing exports and imports are examined separately. Following the standard gravity model, the following augmented gravity model to explain China's processing imports is utilized:

$$
\begin{aligned}
\log \left(P I M_{i t}\right)= & \alpha_{0}+\beta_{1} \log \left(G D P_{i t}\right)+\beta_{2} \log \left(G D P_{c t}\right)+\beta_{3} \log \left(R E X_{i t}\right)+\beta_{4} \log \left(F D I_{i t}\right) \\
& +\beta_{5} \log \left(D_{i}\right)+\alpha_{1} E A_{i}+\alpha_{2} W T O_{t}+\alpha_{3} A C_{i t}+\varepsilon_{i t}
\end{aligned}
$$


where $P I M_{i t}$ stands for real processing imports of China from its trading partner $i$; $G D P_{i t}$ is the real gross domestic products of partner $i$ and $G D P_{c t}$ the real GDP of China; $R E X_{i t}$ denotes real exchange rates between the yuan and the currency of the trading partner $i ; F D I_{i t}$ represents cumulative direct investment in China from partner $i$ from 1985 to year $t ; D_{i}$ measures the distance between China and partner $i ; E A_{i}$ is a dummy variable, equal to one if partner $i$ belong to East Asia, otherwise zero. The coefficient $\alpha_{1}$ represents the common intercept of all East Asian economies and is considered as a quantitative measure on the effect of the production network within the region. $W_{T}$ is a dummy variable indicating the impact of the WTO membership on processing imports and equal to one for the period of 2002 to 2008 . The dummy variable $A C$ is included to measure the impact of the Asian financial crisis in late 1990. It takes value one for year of 1997 and 1998 and zero otherwise.

Real bilateral exchange rates $R E X_{i t}$ is downloaded from the Centre D'Etudes Prospectives et D'Information Internationales (CEPII). Higher real exchange rates imply a real depreciation of the yuan. Hence, if the appreciation of yuan would enhance processing imports, the coefficient $\beta_{3}$ should be negative and significant. The regression equation was estimated with a panel data covering 51 trading partners of China from 1993 to 2008. Processing trade data was provided by China Customs. Processing imports were deflated with the consumer price index of the US. Real GDP and CPI were retrieved from International Financial Statistics of the IMF. The distance between the Chinese capital Beijing and the capital city of partner $i$ was used. Cumulative FDI was computed based on annual FDI inflows published in various issues of the China Statistics Yearbook. The model was estimated with the ordinary least squares (OLS).

Table 1 summarizes the estimates of processing trade. The elasticities of processing imports to the incomes of both China and the destination markets are 0.64 and 0.47 respectively, and statistically significant at $1 \%$. The elasticity to FDI is estimated to be 0.25 and statistically significant at $1 \%$. The coefficient of the geographic distance between China and its trading partners is positive and statistically significant at $5 \%$, suggesting that the transportation cost did not hinder processing imports. The Asian 
financial crisis affected the processing imports negatively as the coefficient of the dummy variable $A C$ is -0.29 and statistically significant at $5 \%$. On the other hand, the WTO membership was not a significant factor in promoting processing imports.

The dummy variable representing East Asian economies is the focal point of the regression. The estimated coefficient of the East Asian dummy $E A$ is 2.26 and statistically significant at $1 \%$, indicating that geographic location of trading partners affected China's processing imports. Using the estimated coefficient, it is straightforward to conclude that China imported 9.6 times more parts and components for processing from East Asian economies than from other regions, should other factors determining processing imports be held constant. This result is consistent with the descriptive fact that the East Asian economies accounted for $77 \%$ of total processing imports. The contribution of FDI in China and incomes of both China and its trading partners to processing imports have been controlled by other independent variables. The estimated regional bias towards East Asia may be attributed to the production networks developed in the region. With regards to real exchange rates, the estimated elasticity is -0.40 and significant at $1 \%$, implying that a $10 \%$ devaluation of the yuan would be expected to result in a $4 \%$ decrease in processing imports.

To identify factors determining processing exports, I used the same model specification to estimate the function of processing exports was used. The estimates are also reported in table 1. The elasticity of processing exports to China's GDP is 1.36 and that to destination market's GDP is 0.54 . Both are statistically significant at $5 \%$. The estimates show that China's GDP—a measure of production capacity_affects exports more than the income of destination markets. Direct investment from trading partners contributed to processing exports positively. For a $10 \%$ increase in cumulative FDI, processing exports to the FDI source economies would be expected to rise $2.9 \%$. Unlike in the case of processing imports, the distances between China and its trading partners reduced the volume of professing exports. The elasticity to distances is -0.33 and significant at $1 \%$.

East Asia remains an important regional factor determining processing exports. On the other hand, the magnitude of the impact is relatively smaller compared with that in processing imports. The coefficient of the East Asian dummy is 0.56 and significant at $1 \%$. The value of the East Asian dummy implies that China's processing exports to the East 
Asian economies are on average 1.8 times higher than that to other regions if other conditions are held constant. The elasticity of processing exports to real exchange rates is estimated 0.08 but statistically insignificant, suggesting that the variations of real exchange rates did not affect China's processing exports. Except for Cheung, et al (2009), all studies on the relationship between the yuan's exchange rates and China's processing exports concluded that the yuan's appreciation would be able to reduce processing exports.

In the regression model, only an East Asian dummy was included. The model was estimated with a panel data. As argued by Chen and Hall (2005), the estimates of standard panel data are biased if no heterogeneity is allowed in the regression equations. With such heterogeneity, a country would export different amounts with two countries, even though the two markets have the same GDP and are equal-distance from the exporter. Destination market specific factors, such as common languages, culture links, history, etc., are the sources of the heterogeneity. Baldwin and Taglioni (2006) argued that the heterogeneity is the "gold medal" problem in estimating gravity models with panel data, and suggested to include country dummies for controlling the heterogeneity and correcting the biasness.

For controlling all possible heterogeneity, the gravity model is re-specified for processing imports/exports as:

$$
\begin{aligned}
\log \left(P I M_{i t}\right)= & \alpha_{0}+\alpha_{i}+\beta_{1} \log \left(G D P_{i t}\right)+\beta_{2} \log \left(G D P_{c t}\right)+\beta_{3} \log \left(R E X_{i t}\right)+\beta_{4} \log \left(F D I_{i t}\right) \\
& +\alpha_{2} W T O_{t}+\alpha_{3} A C_{i t}+\varepsilon_{i t}
\end{aligned}
$$

In equation (2), $\alpha_{i}$ is a country-specific intercept and measures the impact of heterogeneity on processing trade. Since the distance between China and its trading partners represents one aspect of the heterogeneity and is correlated with $\alpha_{i}$, it is excluded in the new model specification. Country dummies for each individual trading partner is employed in the estimation of equation 2. This estimation method is equivalent to the fixed effect model. However, with these country dummies, we are able to quantify the impact of country-specific factors on processing trade and assess whether East Asian economies as a group remains a critical factor to determine China's processing trade. 
Table 2 summaries the estimates of equation 2. According to the new estimates, the exchange rate elasticity of processing exports is 0.96 and significant at $1 \%$, indicating that a $10 \%$ real appreciation of the yuan would give rise to $9.6 \%$ decrease in China's processing exports. This result is consistent with most of existing studies of China's processing exports. On the other hand, processing imports would fall too when the yuan appreciates. The exchange rate elasticity of processing imports is 0.39 and statistically significant at $10 \%$, implying that a $10 \%$ real depreciation of the yuan would lead to a $3.9 \%$ decrease in processing imports. This result apparently contradicts conventional theoretical arguments on the relationship between exchange rates and imports. But, it is consistent with the fundamental nature of processing imports. When processing exports decrease, the demand for processing imports should shrink accordingly as processing imports are the intermediate inputs of processed exports. Since both processing exports and imports fall simultaneously, the impact of the yuan's appreciation on China's trade balance will be limited.

For evaluating the impacts of country-specific factors, the coefficients of East Asian economies' dummies of both processing imports and exports are reported in table 2 . With regards to processing imports, the coefficients of ten East Asian economies' dummies ranged from -0.32 (Japan) to 2.97 (Taiwan) and averaged 1.78; much higher than the average of all country dummies -0.89 . Using the estimated function, we could quantify the difference in the volume of processing imports due to geographic location. Specifically, the estimated regional difference suggests that, China's processing imports from East Asian economies are 13.5 times of that from other regions if other factors are held constant. Excluding Hong Kong and Macau, the processing imports originated from East Asian economies remains 11 times of that from other regions.

The regional bias is also evident in China's processing exports. The coefficients of East Asian economies' dummies are between -0.82 (Japan) and 4.08 (Macau) and average 1.79. The average of all country dummies is 0.09 . Transferring the regional dummy difference into the volume in processing exports implies that, China's processing exports to East Asian economies are 5.5 times of that to other regions. Since most of processing exports to Hong Kong and Macau are re-exported to third countries, the result may overestimate the regional bias in processing exports. Excluding Hong Kong and Macau, 
China's processing exports to the East Asian economies would be 3.1 times of that to other regions should other factors be held constant. Compared with processing imports, the degree of the bias towards East Asia in processing exports is relatively smaller. The empirical results based on the augmented gravity model are consistent with the conclusions derived from descriptive analysis in the section: East Asia is the major source of China's processing imports while the rest of world is the major market of China's processing exports. FDI is included as one of independent variables. The East Asia specific effect should be independent of FDI. Hence, the only meaningful and logic explanation for the significant role of East Asian economies in China's processing trade is the well established production network within the region. As long as China continues to serve as an assembling base for MNEs of East Asian economies, the possibility for substantial decrease in China's processing trade surplus would be very slim. The huge sunk costs is a major obstacle for MNEs to relocate their processing capacities to other countries, unless the yuan would appreciate sharply in the short run.

\section{Concluding Remarks}

Processing trade is a special form of trade. Decomposing China's trade surplus into normal and processing trade suggests that processing trade is the sole contributor to its overall trade surplus. In addition to incomes, FDI, and exchange rates, the geographic factor affected the pattern and volumes of processing trade significantly. Excluding Hong Kong and Macau, China's processing imports from East Asian economies are 11 times of that from other regions while its processing exports to East Asian are 3 times of that to other regions. Both descriptive and econometric analyses indicate that East Asia is the major source of processing imports while the rest of world serves as the destination market of processing exports. This special trading pattern reflects the role of production networks developed by MNEs of East Asian economies in the region and implies a transfer of trade surplus from East Asian economies to China. Therefore, as long as China continues to be used as an export platform, it would be unrealistic to expect China's processing trade surplus to drop substantially in the short run. Our analysis does suggest that the appreciation of the yuan would mitigate processing exports. However, it is equally important to point out that processing imports would decrease too, when the yuan appreciates. Hence, the combined effects of the yuan's appreciation on the balance of processing trade would be very limited. 


\section{References}

Ahmed, S. (2009), "Are Chinese Exports Sensitive to Changes in the Exchange Rate?," International Finance Discussion paper No. 987, Board of Governors of the Federal Reserve System.

Aziz, J. and Li, X. (2007), "China's Changing Trade Elasticities," IMF working paper No. WP/07/266.

Baldwain, R. and Taglioni, D. (2006), "Gravity for dummies and dummies for gravity equations," NBER working paper 12516.

Cheng, I. and Wall, H. (2005), "Controlling for heterogeneity in gravity models of trade and integration," Federal Reserve Bank of St. Louis Review, Jan/Feb 49-62.

Cheung, Y., Chinn, M. and Fujii, E. (2009), "China's Current Account and Exchange Rate," NBER No. 14673.

Garcia-Herrero, A. and Koivu (2009), "China's Exchange Rate Policy and Asian Trade," BIS working paper No. 282.

Kimura, F. and Obashi, A. (2010), "Production Networks in East Asia: What We Know So Far?, paper presented at the conference on "comparative Analysis of Production Networks in Asia and Europe," Vienna, 15-16 July, 2010.

Koopman, R., Wang, Z. and Wei, S. (2008), "How Much of Chinese Exports is Really Made in China? Assessing Domestic Value-added when processing trade is pervasive," NBER working paper 14109.

Thorbecke, W. (2010), "How would an Appreciation of the Yuan affect the people's republic of China's Surplus in processing trade?," ADBI working paper, No. 219, 2010.

Thorbecke, W. and Smith, G. (2010), "How would an appreciation of the Renminbi and other East Asian currencies affect China's exports?", Review of International Economics, forthcoming.

Xing, Y. (2010a), "China's High-tech Exports: Myth and Reality," Background Brief, No. 506, East Asia Institute, the National University of Singapore.

Xing, Y. (2010b), "Facts about and Impacts of FDI on China and the World Economy," China: an International Journal, 8(2): 220-238.

Xing, Y. and Detert, N. (2010), "How the iPhones widens the United Sates' Trade Deficit with PRC," ADBI working paper, No. 257, Asian Development Bank Institute, Tokyo.

Yu, M. (2010), "Processing trade, firms' productivity, and tariff reductions: evidence from Chinese products," CCER working paper. 
Table 1: The Determination of China's Processing Trade: Pooled OLS Estimates

\begin{tabular}{|c|c|c|c|c|}
\hline & \multicolumn{2}{|c|}{ Processing Imports } & \multicolumn{2}{|c|}{ Processing Exports } \\
\hline & Coefficient & Std. Error & Coefficients & Std. Error \\
\hline Constance & -6.37 & 1.55 & -10.40 & 1.17 \\
\hline Log(GDP) & $0.64^{\star \star \star}$ & 0.03 & $0.54^{\star \star \star}$ & 0.03 \\
\hline Log(GDPc) & $0.47^{\star \star \star}$ & 0.18 & $1.36^{\star \star}$ & 0.14 \\
\hline $\log (R E X)$ & $-0.40^{\star \star \star}$ & 0.09 & 0.08 & 1.06 \\
\hline $\log (F D I)$ & $0.25^{\star \star \star}$ & 0.03 & 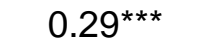 & 0.02 \\
\hline $\log (D)$ & $0.07^{\star \star}$ & 0.08 & $-0.33^{\star \star *}$ & 0.06 \\
\hline EA (East Asia) & $2.26^{\star \star \star}$ & 0.16 & $0.56^{\star \star \star}$ & 0.12 \\
\hline WTO & 0.17 & 0.15 & -0.01 & 0.11 \\
\hline $\begin{array}{c}\text { AC (Asian } \\
\text { Crisis) }\end{array}$ & $-0.29 * \star$ & 0.12 & -0.06 & 0.09 \\
\hline Adj. R-square & \multicolumn{2}{|c|}{0.77} & \multicolumn{2}{|c|}{0.84} \\
\hline Sample size & \multicolumn{2}{|c|}{816} & \multicolumn{2}{|c|}{816} \\
\hline
\end{tabular}


Table 2: The Determination of China's Processing Imports: OLS with country dummies

\begin{tabular}{|c|c|c|c|c|}
\hline & \multicolumn{2}{|c|}{ Processing Imports } & \multicolumn{2}{|c|}{ Processing Exports } \\
\hline & Coefficient & Std. Error & Coefficients & Std. Error \\
\hline Constance & -13.63 & 1.11 & -23.69 & 0.97 \\
\hline Log(GDP) & $1.18^{\star \star \star}$ & 0.23 & $1.25^{\star \star \star}$ & 1.25 \\
\hline $\log (G D P c)$ & $0.90^{\star \star \star}$ & 0.15 & $1.77^{\star \star \star}$ & 1.77 \\
\hline $\log (R E X)$ & $0.39 *$ & 0.11 & $0.96^{\star \star \star}$ & 0.10 \\
\hline Log(FDI) & $0.05^{\star}$ & 0.03 & $0.09^{\star \star \star}$ & 0.03 \\
\hline WTO & 0.08 & 0.07 & -0.10 & 0.06 \\
\hline $\begin{array}{c}\text { AC (Asian } \\
\text { Crisis) }\end{array}$ & $-0.20^{\star \star \star}$ & 0.06 & 0.03 & 0.05 \\
\hline \multicolumn{5}{|l|}{ Country } \\
\hline Hong Kong & 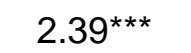 & 0.29 & $4.07^{\star \star \star}$ & 0.25 \\
\hline Indonesia & $0.80^{\star \star}$ & 0.33 & $0.56^{\star \star}$ & 0.29 \\
\hline Japan & -0.32 & 0.91 & -0.82 & 0.79 \\
\hline Macau & $2.32^{\star \star \star}$ & 0.62 & $4.08^{\star \star \star}$ & 0.54 \\
\hline Malaysia & $2.42^{\star \star \star}$ & 0.21 & $2.16^{\star \star \star}$ & 0.18 \\
\hline The Philippines & $1.50^{\star \star \star}$ & 0.20 & $1.76^{\star \star \star}$ & 0.17 \\
\hline Singapore & $2.22^{\star \star \star}$ & 0.22 & $2.70^{\star \star \star}$ & 0.19 \\
\hline Korea & $1.61^{\star \star \star}$ & 0.52 & 0.70 & 0.46 \\
\hline Thailand & $1.87^{\star \star \star}$ & 0.25 & $1.47^{\star \star \star}$ & 0.22 \\
\hline Taiwan & $2.97^{\star \star \star}$ & 0.36 & $1.21^{\star \star \star}$ & 0.32 \\
\hline $\begin{array}{l}\text { The average of } \\
\text { East Asian } \\
\text { economies }\end{array}$ & $1.78^{\star \star \star}$ & 0.24 & $1.79^{\star \star \star}$ & 0.21 \\
\hline $\begin{array}{l}\text { The average of } \\
\text { East Asian } \\
\text { Economies }\end{array}$ & $1.63^{\star \star \star}$ & 0.32 & $1.22^{\star \star \star}$ & 0.28 \\
\hline $\begin{array}{l}\text { excluding Hong } \\
\text { Kong and } \\
\text { Macau }\end{array}$ & & & & \\
\hline $\begin{array}{c}\text { Average of } 51 \\
\text { countries' } \\
\text { dummies }\end{array}$ & $-0.82^{\star \star \star}$ & 0.27 & 0.09 & 0.24 \\
\hline Adj. R-square & \multicolumn{2}{|c|}{0.94} & \multicolumn{2}{|c|}{0.95} \\
\hline Sample size & \multicolumn{2}{|c|}{816} & \multicolumn{2}{|c|}{816} \\
\hline
\end{tabular}




\section{Appendix: China's trading partners covered in the sample}

Argentina, Australia, Austria, Belgium, Brasil, Canada, Chile, Denmark, Finland, France, Germany, Greece, Hong Kong, Hungary, India, Indonesia, Iran, Ireland, Israel, Italy, Japan, Korea, Luxembourg, Macau, Malaysia, Mexico, The Netherlands, New Zealand, Norway, Pakistan, Peru, The Philippines, Poland, Portugal, Romania, Russia, Saudi Arabia, Singapore, South Africa, Spain, Sri Lanka, Sweden, Switzerland, Taiwan, Thailand, Turkey, Ukraine, UK, the US, Uruguay, Vietname. 